\title{
FUNGSI AUPB DALAM PENYELESAIAN SENGKETA ADMINISTRASI PEMILIHAN UMUM \\ (Analisis Putusan Ptun Palembang Nomor: 13/G/2010/PTUN-PLG)
}

\author{
Myaskur \\ Fakultas Hukum Institut Agama Islam Pangeran Diponegoro \\ Jl. HOS Cokroaminoto No.52, Kauman, Kabupaten Nganjuk,Jawa Timur
}

\begin{abstract}
Natural person or private legal person as a legal subject whose interests are affected by the legal consequences of a decision issued by the election administration bodies and/or officers of election administration and therefore the respective aggrieved can file a lawsuit to the administrative court to contest the election administration decisions. The reasons that can be used in the lawsuit are: a). administrative decision which contravenes the laws and regulations that apply; b). administrative decision which contravenes the principles of good governance (AUPB). The court can examine the validity of administrative decisions issued by the agency and/or the election administration officials to resolve concrete issues faced in the conduct of elections in terms of legislation and regulation does not regulate, incomplete, stagnation administration using $A U P B$. It is a manifestation of the principle of ius curia novit that the court may not refuse to examine and try something case filed on the grounds that the law does not or less clear, but obliged to examine and hear.
\end{abstract}

Keywords: dispute, decision, election, administration 


\begin{abstract}
ABSTRAK
Orang atau badan hukum perdata yang berkedudukan sebagai subjek hukum yang kepentingannya terkena oleh akibat hukum keputusan administrasi pemilihan yang dikeluarkan oleh badan dan/atau pejabat administrasi pemilihan dan karenanya yang bersangkutan dirugikan dapat mengajukan gugatan ke pengadilan administrasi untuk menggugat keputusan administrasi pemilihan. Alasan-alasan yang dapat digunakan dalam gugatan adalah: a). keputusan administrasi yang digugat itu bertentangan dengan perundang-undangan dan regulasi yang berlaku; b). keputusan administrasi yang digugat itu bertentangan dengan asas-asas umum pemerintahan yang baik (AUPB). Juga pengadilan dapat menguji keabsahan keputusan administrasi yang diterbitkan oleh badan dan/atau pejabat administrasi pemilihan untuk menyelesaikan isu konkret yang dihadapi dalam penyelenggaraan pemilihan dalam hal perundang-undangan dan regulasi tidak mengatur, tidak lengkap, adanya stagnasi pemilihan dengan menggunakan AUPB. Hal ini sebagai perwujudan asas ius curia novit bahwa pengadilan tidak boleh menolak untuk memeriksa dan mengadili sesuatu perkara yang diajukan dengan dalih bahwa hukum tidak atau kurang jelas, melainkan wajib untuk memeriksa dan mengadilinya.
\end{abstract}

Kata kunci: sengketa, keputusan, pemilihan, administrasi 


\section{A. PENDAHULUAN}

\section{Latar Belakang Masalah}

Kita bangsa Indonesia dalam tahun 2015 telah menyelesaikan pemilihan gubernur, bupati, walikota serentak tahap pertama, yang berlangsung aman, tertib, dan damai. Juga pada tahun 2014 telah diselenggarakan pemilihan umum anggota DPR, DPD, DPRD, Presiden dan Wakil Presiden yang berlangsung secara lancar dan damai. Untuk pemilihan gubernur, bupati, walikota tahun 2015 masih banyak meninggalkan perselisihan hasil pemilihan di Mahkamah Konstitusi dan sengketa administrasi pemilihan yang berlanjut di pengadilan administrasi. Sebagaimana pernyataan Ida Budhiati selaku komisioner KPU RI:

Komisi Pemilihan Umum (KPU) menginginkan revisi UndangUndang Nomor 8 Tahun 2015 tentang Pemilihan Gubernur, Bupati dan Wali Kota mengadopsi pasal terkait sengketa sebagaimana diatur dalam UU DPR, DPRD dan DPD.

Di mana mengatur hanya ada dua objek saja yang bisa diajukan sebagai sebuah penyelesaian sengketa tata usaha negara. Yaitu sengketa pencalonan dan penetapan peserta pemilihan.

Ini yang mestinya ini juga yang diadopsi di dalam UU Pemilihan (Pilkada). Tujuannya, supaya pengaturan tidak berbeda-beda kerangka hukum pemilu antara DPR, DPRD dan DPD, Pilpres dan Pilkada. Karena dalam UU Pilkada saat ini belum ditegaskan objek apa saja yang bisa diajukan sebagai sengketa TUN.

Karenanya tidak heran kalau kemudian terlihat, semua perkara di luar pencalonan dan penetapan pencalonan diajukan oleh pihak-pihak tertentu ke PTUN. Contohnya, pasca putusan MK masih .ada sembilan perkara yang masih diajukan ke PTUN, melawan keputusan KPU tentang penetapan paslon terpilih pasca putusan MK. Padahal menurut undangundang kerangka hukumnya sudah jelas. Kalau MK sudah memutuskan tidak ada usaha lagi untuk mengajukan gugatan berkaitan hasil pemilihan. 
Perubahan perundang-undangan terkait objek sengketa administrasi pemilihan gubernur, bupati, dan walikota (pencalonan dan penetapan peserta pemilihan) sangat penting untuk memberikan kepastian hukum bagi semua pemangku kepentingan pemilihan.

Pemilihan baik yang bersifat nasional dan lokal ini dimaksudkan untuk menyegarkan kepemimpinan yang diharapkan mampu melahirkan visi, misi, dan program pembangunan bagi masyarakat sehingga meningkatkan kesejahteraan bangsa dan negara (de welvaarsstaat). Pemilihan tersebut juga sebagai sarana perwujudan kedaulatan rakyat, berarti rakyatlah yang berkuasa secara penuh untuk menentukan wakilwakilnya yang akan duduk di kursi lembaga legislatif dan eksekutif. Untuk menyelenggarakan pemilihan yang bermartabat dan berkeadilan diperlukan badan administrasi pemilihan yang mampu menjangkau seluruh wilayah Negara Kesatuan Republik Indonesia (nasional), menjalankan tugasnya secara berkesinambungan (tetap), dan bebas dari pengaruh pihak mana pun berkaitan pelaksanaan tugas dan wewenangnya (mandiri). KPU RI, KPU Provinsi, KPU Kabupaten/Kota yang secara hierarkis selaku badan administrasi pemilihan (electoral administration body) yang berwenang dan bertanggungjawab dalam menyelenggarakan pemilihan harus mematuhi asas penyelenggara pemilihan (principles of the implementation of election), aturan hukum pemilihan (electoral law) yang berlaku, kode etik penyelenggara pemilihan. KPU harus bekerja secara efektif (berhasil guna) dan efisien (berdaya guna) dalam menyelenggarakan pemilihan dengan berlandaskan pada asas langsung, umum, bebas, rahasia, jujur dan adil.

Untuk menyelenggarakan pemilihan nasional (national election) maupun pemilihan lokal (local election) pentingnya disusun dan ditetapkan semua tahapan, program, dan jadwal penyelenggaraan pemilihan secara komprehensif dan terpadu untuk memastikan capaian keberhasilan. Keberhasilan dan kelancaran penyelenggaraan pemilihan sangat ditentukan oleh peran serta semua pemangku kepentingan 
pemilihan (stakeholders in the electoral process). Kesadaran peserta pemilihan dalam menggunakan saluran penyelesaian sengketa menurut aturan hukum, kematangan dan kecerdasan masyarakat selaku pemilih, juga ketidakberpihakan dan kejujuran penyelenggara pemilihan (impartial election commission) sangat menentukan kesuksesan pemilihan. Dalam setiap penyelenggaraan pemilihan meskipun sudah diantisipasi dapat saja timbul berbagai pelanggaran kode etik, pelanggaran administrasi, tindak pidana pemilu, dan sengketa administrasi pemilihan. Terkait aturan hukum untuk menyelesaikan sengketa administrasi pemilihan Pemerintah dan DPR telah mengundangkan UU No. 51 Tahun 2009 tentang Perubahan Kedua UU No. 5 Tahun 1986 tentang Peradilan Tata Usaha Negara (PERATUN) menyatakan bahwa sengketa administrasi pemilihan tidak termasuk wewenang Pengadilan Administrasi, tetapi dalam UU No. 42 Tahun 2008 tentang Pemilu Presiden dan Wakil Presiden (UU Pilpres) dan UU No. 8 Tahun 2012 tentang Pemilu Anggota DPR, DPD dan DPRD (UU PILEG) menyatakan bahwa sengketa administrasi pemilihan termasuk wewenang Pengadilan Administrasi dan Undang-Undang Nomor 30 Tahun 2014 tentang Administrasi Pemerintahan (UU AP). Berikutnya juga telah diundangkan Undang-Undang Nomor 8 Tahun 2015 tentang Perubahan atas UU No. 1 Tahun 2015 tentang Penetapan Peraturan Pemerintah Pengganti UU No. 1 Tahun 2014 tentang Pemilihan Gubernur, Bupati, dan Walikota menjadi UU (UU PGBW). Pihak yang secara nyata dirugikan dengan adanya keputusan administrasi pemilihan oleh KPU dapat mengajukan gugatan tertulis ke pengadilan administrasi yang berwenang yang berisi tuntutan agar keputusan administrasi yang disengketakan itu dinyatakan tidak sah.

\section{Rumusan Masalah}

Apakah fungsi AUPB dalam penyelesaian sengketa administrasi pemilihan. 


\section{Tujuan Penelitian}

Untuk mengkaji secara mendalam tentang fungsi AUPB dalam penyelesaian sengketa administrasi pemilihan.

\section{B. PEMBAHASAN}

Penelitian ini bermaksud mengomentari, menganalisis, dan mengkritis putusan PTUN Palembang Nomor: 13/G/2010/PTUN-PLG dan Putusan banding PTTUN Medan dalam register perkara Nomor: 133/B/2010/PT.TUNMDN antara KPU Kabupaten Belitung Timur selaku Tergugat/Pembanding melawan Khairul Efendi selaku Penggugat/Terbanding untuk menemukan ratio decidendi yang berarti alasan-alasan (pertimbangan) hukum yang digunakan oleh hakim untuk sampai kepada putusannya.

\section{Duduk Perkara}

Khairul Efendi selaku Penggugat pada tanggal 14 Mei 2010 mengajukan gugatan kepada KPU Kabupaten Belitung Timur selaku Tergugat yang didaftarkan di Kepaniteraan PTUN Palembang dengan register Nomor: 13/G/ 2010/PTUN-PLG dan diperbaiki pada tanggal 27 Mei 2010 dengan objek sengketa adalah Surat Keputusan KPU Kabupaten Belitung Timur tanggal 1 Mei 2010 Nomor: 25/KEP/KPU.BELTIM/V/2010 tentang Penetapan Pasangan Calon sebagai Peserta Pemilu Bupati dan Wakil Bupati Belitung Timur Tahun 2010.

Khairul Efendi sebagai pejabat Bupati Belitung Timur periode 2005 hingga 2010 pada saat proses Pemilukada Kabupaten Belitung Timur Tahun 2010 mendaftarkan diri sebagai calon Bupati Belitung Timur periode tahun 2010 sampai dengan tahun 2015 berpasangan dengan Erwandi A.Rani.

Berdasarkan Keputusan KPU Kabupaten Belitung Timur Nomor: 25/KEP/KPU.BELTIM/XII/2009 tanggal 1 Mei 2010 tentang Penetapan Pasangan Calon sebagai Peserta Pemilu Bupati dan Wakil Bupati Belitung Timur Tahun 2010, Khairul Efendi 
dinyatakan tidak memenuhi syarat sebagai Calon Bupati dalam Pemilihan Umum Bupati dan Wakil Bupati Belitung Timur Tahun 2010 dengan alasan kesehatan (disabilitas penglihatan jarak pandang mata dengan kemampuan penglihatan 6 derajat) pada penglihatan mata berdasarkan rekomendasi hasil penilaian kesehatan mata Bakal Calon Bupati dan Wakil Bupati Belitung Timur Tahun 2010 Nomor: 01/IV/2010 yang dikeluarkan oleh Tim Penilai Kesehatan Jasmani dan Rohani Bakal Calon Bupati dan Wakil Bupati Belitung Timur Direktorat Kesehatan Angkatan Darat RSPAD Gatot Subroto Jakarta.

Berdasarkan PKPU No. 68 Tahun 2009 tentang Pedoman Teknis Tata Cara Pencalonan Pemilukada Pasal 14 ayat (1) Pemeriksaan sehat jasmani dan rohani sebagaimana dimaksud pada Pasal 9 ayat (1) huruf e dan Pasal 10 huruf b hanya dilakukan oleh Tim Dokter Pemeriksa Khusus dari dan dilakukan di rumah sakit umum daerah berdasarkan rekomendasi dari lembaga yang berwenang yang selanjutnya ditunjuk oleh KPU Provinsi atau KPU Kabupaten/Kota dengan Keputusan KPU Provinsi atau KPU Kabupaten/Kota.

\section{Putusan Perkara}

Terhadap gugatan perkara Nomor: 13/G/ 2010/PTUN-PLG, Majelis Hakim PTUN Palembang dalam putusannya menolak eksepsi KPU Kabupaten Belitung Timur selaku Tergugat, dalam pokok perkara: pertama, mengabulkan gugatan Khairul Efendi selaku Penggugat untuk seluruhnya; Kedua, menyatakan batal Keputusan KPU Kabupaten Belitung Timur tanggal 1 Mei 2010 Nomor: 25/KEP/KPU.BELTIM/XII/2010 tentang Penetapan Pasangan Calon sebagai Peserta Pemilu Bupati dan Wakil Bupati Belitung Timur Tahun 2010; Ketiga, memerintahkan Tergugat untuk mencabut Keputusan KPU Kabupaten Belitung Timur Nomor: 25/KEP/KPU.BELTIM/XII/2010; Keempat, 
memerintahkan kepada Tergugat untuk menerbitkan keputusan baru yang menetapkan Khairul Efendi turut serta sebagai Calon Kandidat dalam Pemilu Bupati dan Wakil Bupati Belitung Timur Tahun 2010; Kelima, menghukum Tergugat untuk taat dan patuh terhadap isi putusan; Keenam, menghukum Tergugat untuk membayar perkara yang timbul dalam sengketa ini sebesar Rp. 101.000,00 (seratus satu ribu rupiah). Adapun pertimbangan hukum Majelis Hakim PTUN Palembang perihal eksepsi Tergugat:

ad.1. Eksepsi kompetensi absolut. Terhadap dalil eksepsi Tergugat yang menyatakan bahwa PTUN Palembang tidak berwenang mengadili sengketa TUN, Majelis Hakim berpendapat bahwa berdasarkan ketentuan Pasal 47 jo. Pasal 1 angka $10 \mathrm{UU}$ PERATUN, objek sengketa Keputusan KPU Kabupaten Belitung Timur Nomor: 25/KEP/KPU.BELTIM/XII/2010 telah memenuhi unsur-unsur KTUN secara kumulatif sebagaimana diatur dalam Pasal 1 angka 9 dan tidak termasuk dalam ruang lingkup keputusan yang diatur dalam Pasal 2 dan Pasal 49 UU PERATUN. Berarti sengketa TUN sebagaimana dimaksud dalam Pasal 1 angka 10 UU PERATUN.

Mengenai upaya administratif sebagaimana dimaksud dalam Pasal 48 UU PERATUN dalam penjelasan dinyatakan: "Dari ketentuan dalam peraturan perundang-undangan yang menjadi dasar dikeluarkannya KTUN yang bersangkutan dapat dilihat apakah terhadap suatu KTUN itu terbuka atau tidak terbuka kemungkinan untuk ditempuh suatu upaya administratif'. Berdasarkan peraturan perundang-undangan khususnya PKPU No. 68 Tahun 2009 tentang Pedoman Teknis Tata Cara Pencalonan Pemilukada Majelis Hakim berpendapat bahwa terhadap objek sengketa TUN dalam peraturan perundang-undangan tersebut tidak terdapat ketentuan yang memungkinkan untuk ditempuh suatu upaya administratif terhadap keputusan KPU tentang penetapan pasangan calon sebagai peserta 
Pemilu Bupati dan Wakil Bupati, sehingga eksepsi tergugat haruslah dinyatakan ditolak.

Ad.2. Error in persona. Berdasarkan Pasal 53 ayat 1 UU PERATUN dan asas dalam Hukum Acara Tata Usaha Negara yang menyebutkan bila tidak ada kepentingan, maka tidak dapat mengajukan gugatan (no interest, no action). Berarti kualitas Penggugat untuk mengajukan gugatan ditentukan oleh ada atau tidak adanya kepentingan Penggugat yang dirugikan secara langsung oleh objek sengketa TUN. Oleh karena Penggugat merupakan salah satu nama yang disebut dalam objek sengketa TUN, maka terdapat kepentingan Penggugat yang dirugikan secara langsung oleh terbitnya objek sengketa TUN, sebab dengan terbitnya sengketa TUN Penggugat menjadi kehilangan hak untuk menjadi Peserta dalam Pemilu Bupati dan Wakil Bupati Kabupaten Belitung Timur Tahun 2010 sehingga Penggugat mempunyai kualitas dan kepentingan untuk menggugat.

Salah satu karakteristik PTUN adalah putusan pengadilan bersifat erga omnes. Berbeda dengan sengketa perdata dimana putusan hakim perdata hanya mengikat terhadap pihak-pihak yang bersengketa, sedangkan putusan PTUN tidak hanya mengikat terhadap pihak-pihak yang bersengketa, akan tetapi berlaku juga terhadap pihak-pihak yang terkait diluar pihak yang bersengketa. Meskipun yang menggugat objek sengketa TUN hanya calon Bupati saja, akan tetapi apabila sengketa TUN telah diputus PTUN, maka putusan tersebut berlaku juga untuk Bakal Calon Wakil Bupati sekalipun tidak turut menggugat objek sengketa TUN.

Berdasarkan Pasal 1 angka 9 dan angka 12 UU PERATUN, Majelis Hakim berpendapat Penggugat telah tepat menggugat keputusan tergugat, sebab keputusan telah memenuhi secara kumulatif unsur-unsur ketentuan Pasal 1 angka 9 UU PERATUN, sementara keputusan atau penetapan sebelum objek sengketa 
diterbitkan merupakan tahapan persiapan untuk dapat terbitnya objek sengketa. Berdasarkan pertimbangan diatas Majelis Hakim berkeyakinan bahwa tidak terbukti adanya error in persona dalam gugatan penggugat, sehingga eksepsi Tergugat mengenai error in persona harus dinyatakan ditolak.

Ad.3. Obscuur libel. Majelis Hakim berpendapat gugatan tersebut telah jelas menyebutkan objek sengketanya KTUN sebagaimana dimaksud Pasal 1 angka 9 UU PERATUN, juga secara jelas menunjukkan perbuatan Tergugat dalam menerbitkan objek sengketa bertentangan dengan peraturan perundang-undangan yang berlaku dan menunjukkan kepentingan yang dirugikan oleh terbitnya objek sengketa, sehingga gugatan Penggugat tidak salah objek. Berdasarkan Pasal 97 ayat (8) dan (9) UU PERATUN menyebutkan:

(8).Dalam hal gugatan dikabulkan, maka dalam putusan Pengadilan tersebut dapat ditetapkan kewajiban yang harus dilakukan oleh Badan atau Pejabat TUN yang mengeluarkan KTUN.

(9).Kewajiban sebagaimana dimaksud dalam ayat (8) berupa:

a. pencabutan KTUN yang bersangkutan; atau

b. pencabutan KTUN yang bersangkutan dan menerbitkan Keputusan Tata Usaha Negara yang baru; atau

c. Penerbitan KTUN dalam hal gugatan didasarkan pada Pasal 3

Majelis Hakim berpendapat bahwa petitum yang diajukan penggugat pada intinya telah sesuai dengan ketentuan yang berlaku, sehingga eksepsi tergugat mengenai obscuur libel haruslah dinyatakan tidak diterima.

Pertimbangan hukum majelis hakim dalam pokok perkara dilakukan lewat pengujian keabsahan (rechtmatigheidstoetsing) terhadap objek sengketa a quo:

a. Kewenangan Tergugat dalam menerbitkan objek sengketa;

b. Substansi dan prosedur mengenai objek sengketa; dan 
c. Asas-asas Umum Pemerintahan yang Baik (AUPB).

Ada Kewenangan Tergugat dalam menerbitkan obyek sengketa. Berdasarkan Pasal 1 angka 4, angka 5 dan angka 7 Undang-Undang Nomor 22 Tahun 2007 tentang Penyelenggara Pemilihan Umum disebutkan:

(1). Pemilu Kepala Daerah dan Wakil Kepala Daerah adalah Pemilu untuk memilih kepala daerah dan wakil kepala daerah secara langsung dalam Negara Kesatuan Republik Indonesia berdasarkan Pancasila dan Undang-Undang Dasar Negara Republik Indonesia Tahun 1945.

(2). Penyelenggara Pemilihan Umum adalah lembaga yang menyelenggarakan Pemilu untuk memilih anggota Dewan Perwakilan Rakyat, Dewan Perwakilan Daerah, Dewan Perwakilan Rakyat Daerah dan Presiden dan Wakil Presiden, serta kepala daerah dan wakil kepala daerah secara langsung oleh rakyat.

(7). Komisi Pemilihan Umum Provinsi dan Komisi Pemilihan Umum Kabupaten/Kota, selanjutnya disebut KPU Provinsi dan KPU Kabupaten/Kota, adalah Penyelenggara Pemilu di provinsi dan kabupaten/kota.

Pasal 39 ayat (1) PKPU No. 68 Tahun 2009 tentang Pedoman Teknis Tata Cara Pencalonan Pemilukada menyebutkan: "Berdasarkan hasil penelitian, KPU Provinsi atau KPU Kabupaten/Kota menetapkan nama-nama pasangan calon yang memenuhi syarat sebagai peserta Pemilukada sekurang-kurangnya 2 (dua) pasangan calon yang dituangkan dalam Berita Acara penetapan pasangan calon". Majelis Hakim berkesimpulan Tergugat memiliki kewenangan untuk menerbitkan objek sengketa TUN.

Ad.b. Substansi dan prosedur mengenai objek sengketa. Berdasarkan ketentuan Pasal 6 huruf b PKPU No. 62 Tahun 2009 tentang Pedoman Penyusunan Tahapan, Program dan Jadwal Penyelenggaraan Pemilukada, Kegiatan Tahapan Pelaksanaan sebagaimana dimaksud dalam Pasal 5 huruf b angka 2, meliputi: $b$. Pencalonan, dengan alur pemilihan sebagai berikut: 
1. Pengumuman pencalonan Kepala Daerah dan Wakil Kepala Daerah;

2. Penyerahan dukungan calon perseorangan di KPU Kabupaten/Kota dan/atau KPU Provinsi serta seluruh PPS;

3. Verifikasi calon perseorangan di PPS, PPK, KPU Kabupaten/Kota, dan/atau KPU Provinsi;

4. Pendaftaran Pasangan Calon Kepala Daerah dan Wakil Kepala Daerah oleh Parpol/Gabungan Parpol dan perseorangan;

5. Penyampaian hasil pemeriksaan Kesehatan Pasangan Calon Kepala Daerah dan Wakil Kepala Daerah oleh Parpol/Gabungan Parpol kepada KPU Provinsi atau KPU Kabupaten/Kota;

6. Penelitian administratif syarat pengajuan pasangan calon dan syarat calon serta dukungan calon perseorangan;

7. Penyampaian/pemberitahuan hasil penelitian;

8. Perbaikan kelengkapan/syarat pasangan calon dan penambahan dukungan calon perseorangan;

9. Verifikasi tambahan dukungan calon perseorangan di PPS, PPK, dan KPU Kabupaten/Kota;

10. Penelitian ulang kelengkapan dan perbaikan persyaratan pasangan calon;

11. Pengumuman pasangan calon yang memenuhi persyaratan;

12. Penetapan, Penentuan Nomor Urut dan Pengumuman pasangan Calon Kepala Daerah dan Wakil Kepala Daerah.

Penyampaian hasil pemeriksaan Kesehatan Pasangan Calon Kepala Daerah dan Wakil Kepala Daerah oleh Parpol/Gabungan Parpol kepada KPU Provinsi atau KPU Kabupaten/Kota paling 
lambat 81 hari sebelum hari pemungutan suara, sementara penelitian administratif syarat pengajuan pasangan calon dan syarat calon serta dukungan calon perseorangan paling lambat 80 hari sebelum hari pemungutan suara. Majelis Hakim menyimpulkan Penyampaian hasil pemeriksaan Kesehatan Pasangan Calon Kepala Daerah dan Wakil Kepala Daerah dilakukan lebih dahulu sebelum kelengkapan dan syarat pasangan calon dan hal ini tidak menyalahi peraturan perundang-undangan.

Berdasarkan ketentuan Pasal 2 Undang-Undang Nomor 22 Tahun 2007 tentang Penyelenggara Pemilihan Umum jo. Pasal 3 huruf d PKPU No. 62 Tahun 2009 menyebutkan: "Penyelenggara Pemilihan Umum Kepala Daerah dan Wakil Kepala Daerah berpedoman pada Asas Kepastian Hukum”. Ketentuan Pasal 14 ayat (1), (2) dan (3) PKPU No. 68 Tahun 2009 menyebutkan:

(1). Pemeriksaan sehat jasmani dan rohani sebagaimana dimaksud dalam Pasal 9 ayat (1) huruf e dan Pasal 10 huruf $b$ hanya dilakukan oleh tim Dokter pemeriksa khusus dan dilakukan dirumah sakit umum daerah berdasarkan rekomendasi dari lembaga yang berwenang yang selanjutnya ditunjuk oleh KPU Provinsi atau KPU Kabupaten/Kota dengan Keputusan KPU Provinsi atau KPU Kabupaten/Kota. (2). Hasil Pemeriksaan sebagaimana dimaksud pada ayat 1 disampaikan oleh tim Dokter pemeriksa khusus kepada KPU Provinsi atau KPU Kabupaten/Kota sebagai pembuktian kebenaran kelengkapan persyaratan pasangan calon.

(3). Hasil Pemeriksaan sebagaimana dimaksud pada ayat 1 bersifat final, yaitu tidak dimungkinkan lagi untuk dilakukan pemeriksaan yang sama dirumah sakit lain sebagai pembanding.

Dalam rangka menjamin asas Kepastian Hukum penyelenggaraan Pemilu Bupati dan Wakil Bupati Belitung Timur maka Tergugat harus menjalankan ketentuan Pasal 14 ayat (1), (2) dan (3) Peraturan KPU No. 68 Tahun 2009 secara benar dan bertanggung jawab. Merujuk ketentuan Pasal 14 ayat (1) juncto Pasal 29 ayat (1) Peraturan KPU No. 68 Tahun 2009 tentang 
Pedoman Teknis Tata Cara Pencalonan Pemilihan Umum Kepala Daerah dan Wakil Kepala Daerah jo. Penjelasan Pasal 38 ayat (1) huruf e Peraturan Pemerintah No. 49 Tahun 2008 tentang Perubahan Ketiga atas Peraturan Pemerintah Nomor 6 tahun 2005 tentang Pemilihan, Pengesahan Pengangkatan dan Pemberhentian Kepala Daerah dan Wakil Kepala Daerah, dinyatakan pemeriksaan kesehatan bakal calon Kepala Daerah dan Wakil Kepala Daerah dilakukan oleh Tim Dokter Pemeriksa Khusus dari dan dilakukan di Rumah Sakit Umum Daerah. Rumah Sakit Umum Daerah adalah Rumah Sakit Umum yang ada di Daerah dan dibentuk atau diatur dengan Peraturan Daerah.

Pemeriksaan kesehatan bakal calon Bupati dan Wakil Bupati Belitung Timur Tahun 2010 dilakukan di RSPAD Gatot Subroto Jakarta tertuang dalam Surat Keputusan Tim Penilai Kesehatan Jasmani dan Rohani Bakal Calon Bupati dan Wakil Bupati Belitung Timur Tahun 2010 No. 01/IV/2010 tanggal 8 April 2010 sebagai dasar terbitnya objek sengketa mengandung cacat hukum. Pemeriksaan kesehatan bakal calon Bupati dan Wakil Bupati Belitung Timur Tahun 2010 di RSPAD Gatot Subroto telah menyalahi ketentuan Pasal 14 ayat (1) jo. Pasal 29 ayat (1) PKPU No. 68 Tahun 2009 tentang Pedoman Teknis Tata Cara Pencalonan Pemilihan Umum Kepala Daerah dan Wakil Kepala Daerah, maka objek sengketa Keputusan KPU Kab. Belitung Timur No.25/KEP/KPU.BELTIM/XII/2010 tentang penetapan pasangan calon sebagai peserta Pemilu Bupati dan Wakil Bupati Belitung Timur Tahun 2010 tanggal 1 Mei 2010 juga harus dinilai cacat hukum, sehingga harus dibatalkan.

Ad.c. Asas-asas Umum Pemerintahan yang Baik (AUPB). Asas kepastian hukum formal agar setiap Pejabat Tata Usaha Negara dalam melaksanakan urusan pemerintahan selalu berpedoman dan mematuhi hal-hal yang sudah diatur secara 
tersurat (expressive verbis) dalam peraturan perundang-undangan yang berlaku agar terwujud tata kehidupan berbangsa dan bernegara yang tertib, serasi dan seimbang antara pemerintah dan warga masyarakat. Terbukti Tergugat tidak mematuhi Pasal 38 ayat (1) huruf e Peraturan Pemerintah Nomor 49 Tahun 2008 tentang Perubahan Ketiga atas Peraturan Pemerintah Nomor 6 tahun 2005 tentang Pemilihan, Pengesahan Pengangkatan dan Pemberhentian Kepala Daerah dan Wakil Kepala Daerah jo. Pasal 14 ayat (1) PKPU No. 68 Tahun 2009 tentang Pedoman Teknis Tata Cara Pencalonan Pemilihan Umum Kepala Daerah dan Wakil Kepala Daerah. Dengan demikian Majelis Hakim berpendapat bahwa Tergugat telah melanggar asas kepastian hukum formal. Asas kecermatan setiap Pejabat TUN dalam menerbitkan KTUN diharuskan bertindak secara cermat didalam menerapkan peraturan perundang-undangan yang berlaku.

Terbukti Tergugat telah bertindak tidak cermat dalam menafsirkan dan menerapkan ketentuan yang mengatur tentang proses pemeriksaan kesehatan bakal calon Bupati dan Wakil Bupati Belitung Timur Tahun 2010, sehingga Majelis Hakim berpendapat bahwa Tergugat dalam menerbitkan keputusan objek sengketa juga telah melanggar asas kecermatan. Oleh karena objek sengketa telah diterbitkan bertentangan dengan peraturan perundang-undangan yang berlaku dan asas-asas umum pemerintahan yang baik, sehingga harus dinyatakan batal atau dicabut, maka gugatan penggugat haruslah dikabulkan.

Terhadap putusan PTUN Palembang Nomor: 13/G/2010/PTUN-PLG, KPU Kabupaten Belitung Timur selaku Tergugat/Pembanding mengajukan banding kepada PTUN Medan dalam register perkara Nomor: 133/B/2010/PT.TUN-MDN. Berkaitan banding ini Majelis Hakim PTTUN Medan tanggal 24 Agustus 2010 mengadili menguatkan putusan PTUN Palembang 
tanggal 30 Juni 2010 Nomor: 13/G/2010/PTUN-PLG. Adapun pertimbangan hukum Majelis Hakim PTTUN Medan sebagai judex facti ditingkat banding berpendapat dan berkesimpulan bahwa pertimbangan hukum dan putusan PTUN Palembang tersebut telah tepat dan benar sesuai dengan hukum yang berlaku, oleh karena itu pertimbangan hukum dimaksud diambil alih menjadi pertimbangan hukum di tingkat banding. Putusan banding tersebut telah berkekuatan hukum tetap (inkracht van gewijsde vonnis), karena KPU Kabupaten Belitung Timur menerima putusan dan tidak melakukan upaya hukum lagi.

\section{Analisis Hukum}

Karakteristik atau ciri khas Hukum Acara Peradilan Administrasi terletak pada asas-asas hukum yang melandasinya, yaitu:

a. asas praduga rechtmatig (vermoeden van rechtmatigheid = praesumptio iustae causa). Asas ini mengandung makna bahwa setiap tindakan penguasa selalu harus dianggap rechtmatig sampai ada pembatalannya. Dengan asas ini, gugatan tidak menunda pelaksanaan KTUN yang digugat (ps. 67 ayat $1 \mathrm{UU}$ no. 5 th. 1986);

b. asas pembuktian bebas. Hakim yang menetapkan beban pembuktian. Hal ini berbeda dengan ketentuan ps. 1865 BW. Asas ini dianut pasal 107 UU no. 5 th. 1986 hanya saja masih dibatasi ketentuan pasal 100 .

c. asas keaktifan hakim (dominus litis). Keaktifan hakim dimaksudkan untuk mengimbangi kedudukan para pihak karena tergugat adalah pejabat tata usaha negara sedangkan penggugat adalah orang atau badan hukum perdata. Penerapan asas ini antara lain terdapat dalam ketentuan pasal: 58,63 ayat $1,2,80,85$. 
d. asas putusan pengadilan mempunyai kekuatan mengikat "erga omnes". Sengketa TUN adalah sengketa hukum publik. Dengan demikian putusan pengadilan TUN berlaku bagi siapa saja - tidak hanya bagi para pihak yang bersengketa. Dalam rangka ini kiranya ketentuan pasal 83 tentang intervensi bertentangan dengan asas "erga omnes".।

e. Asas praduga rechtmatig (vermoeden van rechtmatigheid $=$ praesumptio iustae causa), gugatan Khairul Efendi dengan objek Keputusan KPU Kabupaten Belitung Timur tanggal 1 Mei 2010 Nomor: 25/KEP/KPU.BELTIM/XII/2010 tentang Penetapan Pasangan Calon sebagai Peserta Pemilu Bupati dan Wakil Bupati Belitung Timur Tahun 2010 tidak menunda pelaksanaan tahapan penyelenggaraan Pemilukada Kabupaten Belitung Timur Tahun 2010 dan harus dianggap rechtmatig sampai ada pembatalan melalui putusan pengadilan yang berkekuatan hukum tetap (inkracht van gewijsde vonnis) sebagaimana dimaksud dalam ketentuan Pasal 67 ayat (1) UU PERATUN, "Gugatan tidak menunda atau menghalangi dilaksanakannya Keputusan Badan atau Pejabat Tata Usaha Negara serta tindakan Badan atau Pejabat Tata Usaha Negara yang digugat".

Permohonan penundaan keputusan objek sengketa a quo oleh Penggugat menurut Majelis Hakim tidak dapat dikabulkan, sebab tidak memenuhi kriteria, khususnya Pasal 67 ayat (4) UU PERATUN, yaitu penundaan harus memenuhi syarat-syarat sebagai berikut:

a.Dapat dikabulkan hanya apabila terdapat keadaan yang sangat mendesak yang mengakibatkan kepentingan penggugat sangat dirugikan jika KTUN yang digugat itu tetap dilaksanakan; 
b. Tidak dapat dikabulkan apabila kepentingan umum dalam rangka pembangunan mengharuskan dilaksanakannya keputusan tersebut.

Majelis Hakim telah menerapkan asas praduga rechtmatig secara konsisten dengan menolak permohonan penundaan oleh Penggugat. Ini selaras dengan pemikiran Peter Mahmud Marzuki, apabila terjadi benturan antara prinsip hukum dan aturan hukum yang harus diacu adalah prinsip hukum. Ketentuan Pasal 67 ayat (2), (3) dan (4) UU PERATUN dikesampingkan sebab membatasi keberlakuan asas praduga rechtmatig. Juga dalam dictum putusan perkara Nomor: 13/G/ 2010/PTUN-PLG tidak memerintahkan penundaan tahapan penyelenggaraan Pemilukada Kabupaten Belitung Timur Tahun 2010, hanya menyatakan batal Keputusan KPU Kabupaten Belitung Timur tanggal 1 Mei 2010 Nomor: 25/KEP/KPU.BELTIM/XII/2010 tentang Penetapan Pasangan Calon sebagai Peserta Pemilu Bupati dan Wakil Bupati Belitung Timur Tahun 2010 dan memerintahkan kepada KPU Kota Depok untuk mencabut keputusan tersebut.

Amar putusan hanya menyatakan batal dan untuk mencabut keputusan tersebut, hal ini sesuai dengan makna asas rechtmatig bahwa keputusan organ pemerintahan hanya dapat dibatalkan (vernietigbaar) dan bukan batal demi hukum (van rechtswege nietig).

Asas pembuktian bebas (vrij bewijs). Majelis Hakim telah tepat dalam pertimbangan hukumnya, dengan memperhatikan segala sesuatu yang terjadi dalam pemeriksaan persidangan tanpa tergantung pada fakta-fakta dan hal-hal yang diajukan oleh Para Pihak sesuai dengan ketentuan Pasal 107 UU PERATUN. Majelis Hakim telah mengambil beban pembuktian beserta penilaian pembuktian, atas dasar itu terhadap alat-alat bukti yang diajukan Para Pihak menjadi bahan pertimbangan, namun untuk mengadili 
dan memutus sengketanya hanya dipakai alat bukti yang relevan dan terhadap alat bukti yang selebihnya tetap dilampirkan dan menjadi satu kesatuan dengan berkas perkaranya. Asas ini ditulis dalam Pasal 107 UU PERATUN, "Hakim menentukan apa yang harus dibuktikan, beban pembuktian beserta penilaian pembuktian, dan untuk sahnya pembuktian diperlukan sekurang-kurangnya dua alat bukti berdasarkan keyakinan Hakim". Berarti asas pembuktian bebas (vrij bewijs) memuat empat aspek: apa yang harus dibuktikan (bewijsomvang), beban pembuktian (bewijslastverdeling), penilaian pembuktian (bewijswaardering), dan alat bukti (bewijsmiddelen).

Hanya saja ketentuan Pasal 107 masih dibatasi ketentuan Pasal 100, "alat bukti ialah: surat atau tulisan, keterangan ahli, keterangan saksi, pengakuan para pihak dan pengetahuan hakim". Bahkan majelis hakim dalam pertimbangan hukumnya (ratio decidendi) juga menggunakan Asas-asas Umum Pemerintahan yang Baik/AUPB (algemene beginselen van behoorlijk bestuur) sebagai alat uji keabsahan keputusan administrasi pemilihan, yakni asas kepastian hukum dan asas larangan penyalahgunaan wewenang (larangan bertindak sewenang-wenang). Asas kepastian hukum yang berarti Badan dan/atau Pejabat Administrasi (KPU) telah mengambil keputusan dan/atau tindakan yang bertentangan dengan perundang-undang dan regulasi pemilihan. Asas larangan bertindak sewenang-wenang Badan dan/atau Pejabat Administrasi (KPU) telah mengambil keputusan dan/atau tindakan yang tidak berdasarkan kewenangan sebagai penyelenggara pemilihan.

Asas keaktifan hakim (actieve rechter = dominus litis), dimaksudkan untuk mengimbangi kedudukan para pihak karena tergugat adalah Badan atau Pejabat Administrasi (KPU Kab. Belitung Timur) sedangkan penggugat adalah orang atau badan hukum perdata (Khairul Efendi). Asas ini tertuang dalam ketentuan UU PERATUN : 


\section{Pasal 58}

Apabila dipandang perlu Hakim berwenang memerintahkan kedua belah pihak yang bersengketa datang menghadap sendiri ke persidangan, sekalipun sudah diwakili oleh seorang kuasa.

\section{Pasal 63}

(1). Sebelum pemeriksaan pokok sengketa dimulai, Hakim wajib mengadakan pemeriksaan persiapan untuk melengkapi gugatan yang kurang jelas.

(2). Dalam pemeriksaan persiapan sebagaimana dimaksud dalam ayat (1) Hakim:

a. wajib memberi nasihat kepada penggugat untuk memperbaiki gugatan dan melengkapinya dengan data yang diperlukan dalam jangka waktu tiga puluh hari;

b. dapat meminta penjelasan kepada Badan atau Pejabat Tata Usaha Negara yang bersangkutan.

\section{Pasal 80}

Demi kelancaran pemeriksaan sengketa, Hakim Ketua Sidang berhak di dalam sidang memberikan petunjuk kepada para pihak yang bersengketa mengenai upaya hukum dan alat bukti yang dapat digunakan oleh mereka dalam sengketa.

\section{Pasal 85}

(1). Untuk kepentingan pemeriksaan dan apabila Hakim Ketua Sidang memandang perlu ia dapat memerintahkan pemeriksaan terhadap surat yang dipegang oleh Pejabat Tata Usaha Negara, atau pejabat lain yang menyimpan surat, atau meminta penjelasan dan keterangan tentang sesuatu yang bersangkutan dengan sengketa.

(2). Selain hal sebagaimana dimaksud dalam ayat (1) Hakim Ketua Sidang dapat memerintahkan pula supaya surat tersebut diperlihatkan kepada Pengadilan dalam persidangan yang akan ditentukan untuk keperluan itu.

(3). Apabila surat itu merupakan bagian dari sebuah daftar, sebelum diperlihatkan oleh penyimpannya, dibuat salinan surat itu sebagai ganti yang asli selama surat yang asli belum diterima kembali dari Pengadilan.

(4). Jika pemeriksaan tentang benarnya suatu surat menimbulkan persangkaan terhadap orang yang masih hidup bahwa surat itu dipalsukan olehnya, Hakim Ketua Sidang dapat mengirimkan surat yang bersangkutan ini kepada penyidik yang berwenang, dan pemeriksaan sengketa Tata Usaha Negara dapat ditunda dahulu sampai putusan perkara pidananya dijatuhkan. 
Keaktifan Majelis Hakim dapat ditelusuri dalam pemeriksaan dengan menaati dan menempuh prosedur yang ada, yakni: Penetapan Dismisal (Pasal 62 ayat (1) UU PERATUN), penunjukkan Majelis Hakim yang memeriksa, memutus dan menyelesaikan sengketa TUN tersebut, Pemeriksaan Persiapan sengketa tersebut [Pasal 63 ayat (1) dan (2)], Penetapan Hari Sidang pertama pemeriksaan sengketa tersebut, Surat-surat bukti dari keduabelah pihak yang bersengketa dan Berita Acara persidangan, mendengar keterangan kedua belah pihak dan keterangan saksisaksi dari keduabelah pihak yang bersengketa.

Asas putusan pengadilan memiliki kekuatan mengikat erga omnes (bagi semua). Menurut Suparto Wijoyo, asas erga omnes adalah: Nalar adanya konsekuensi (karakteristik) ini ialah, sengketa TUN (administrasi) adalah sengketa hukum publik (hukum administrasi). Putusan hakim Peradilan Administrasi merupakan putusan hukum publik (mempunyai karakter hukum publik). Dengan demikian, putusan hakim Peradilan Administrasi berlaku bagi siapa saja, tidak hanya bagi para pihak yang bersengketa semata.

Artinya putusan PTUN Palembang Nomor: 13/G/2010/PTUN-PLG dan Putusan banding PTTUN Medan dalam register perkara Nomor: 133/B/2010/PT.TUN-MDN tidak hanya berlaku bagi pihak yang bersengketa saja, yaitu: antara Khairul Efendi dengan KPU Kab. Belitung Timur, tetapi berlaku dan mengikat bagi siapa saja. Adanya ketentuan Pasal 83 UU PERATUN tentang intervensi sangat bertentangan dengan asas erga omnes, hal ini sangat dipengaruhi oleh ketentuan hukum acara perdata, sebab sifat putusan pengadilan perdata hanya berlaku bagi pihak-pihak yang berperkara saja.

Majelis hakim bertindak tepat dan benar dengan melakukan pengujian keabsahan penerbitan surat Keputusan Nomor: 
25/KEP/KPU.BELTIM/XII/2010 menggunakan AUPB, khususnya asas kepastian hukum (rechtszekerheidsbeginsel) dan asas kecermatan (zorgvuldigheidsbeginsel) sebagaimana yang dimaksud dalam Pasal 53 ayat (2), yaitu KTUN yang digugat itu bertentangan dengan AUPB. Aspek asas kepastian hukum, KPU Kab. Belitung Timur terbukti tidak mematuhi Pasal 38 ayat (1) huruf e PP No. 49 Tahun 2008 tentang Perubahan Ketiga atas PP No. 6 tahun 2005 tentang Pemilihan, Pengesahan Pengangkatan dan Pemberhentian Kepala Daerah dan Wakil Kepala Daerah jo. Pasal 14 ayat (1) PKPU No. 68 Tahun 2009 tentang Pedoman Teknis Tata Cara Pencalonan Pemilihan Umum Kepala Daerah dan Wakil Kepala Daerah. Aspek asas kecermatan KPU Kab. Belitung Timur terbukti tidak melakukan pekerjaan persiapan secara tepat dan akurat dengan meneliti fakta-fakta dan segala kepentingan yang relevan.

Putusan PTUN perkara No. 13/G/2010/PTUN-PLG dan putusan banding PTTUN perkara Nomor: 133/B/2010/PT.TUNMDN telah mempunyai kekuatan hukum tetap (inkracht van gewijsde vonnis) karena pihak-pihak yang bersengketa tidak melakukan upaya hukum lagi dan menerima putusan ini. Tetapi yang perlu dicatat dan bersifat problematis dalam sengketa ini, bahwa putusan ini tidak dapat dieksekusi sebab pelaksanaan pemilukada terus berlanjut sesuai tahapannya. Tergugat/Pembanding KPU Kab. Belitung Timur tidak mau melaksanakan putusan banding dengan alasan mematuhi tahapan pemilihan yang telah ditetapkan. Alasan KPU Kab. Belitung Timur yang tetap bersikukuh mematuhi tahapan pemilihan, disisi lain merugikan hak-hak pencari keadilan pasangan calon bupati dan wakil bupati yang telah memenangkan gugatan administrasi tersebut. Inilah hambatan-hambatan dalam eksekusi putusan sengketa administrasi pemilihan sehingga melahirkan ketidakadilan 
pemilihan atau menang di atas kertas tetapi tidak dapat diwujudkan dalam kenyataan.

\section{PENUTUP}

\section{Kesimpulan}

Fungsi Asas-asas Umum Pemerintahan yang Baik (AUPB) atau Algemene Beginselen van Behoorlijk Bestuur, dalam penyelesaian sengketa administrasi pemilihan kepala daerah adalah sangat berfungsi. Bahwa orang dan/atau badan hukum perdata dapat mengajukan gugatan administrasi pemilihan melawan badan dan/atau pejabat administrasi pemilihan kepada pengadilan administrasi dengan menggunakan alasan bahwa keputusan administrasi yang digugat itu bertentangan dengan perundang-undangan dan regulasi yang berlaku dan/atau keputusan administrasi yang digugat itu bertentangan dengan Asas-asas Umum Pemerintahan yang Baik (AUPB).

Pengadilan administrasi (administrative court) dalam membatalkan (menyatakan sah atau tidak sah) keputusan administrasi pemilihan harus terlebih dahulu menguji keabsahan (rechtmatigheidstoetsing) keputusan administrasi pemilihan tersebut apakah terdapat cacat wewenang, prosedur, dan/atau substansi dengan berdasarkan perundang-undangan dan regulasi dengan langkah-langkah penemuan hukum (rechtsvinding) melalui cara interpretasi dan asas preferensi hukum. Sedangkan untuk keputusan bebas (vrije beschikking) atau diskresi yang diambil berdasarkan asas freies ermessen oleh badan dan/atau pejabat administrasi karena perundang-undangan dan regulasi belum atau tidak mengatur, hakim yang memeriksa, mengadili, dan memutus sengketa administrasi pemilihan wajib menguji keabsahan nya dengan menerapkan AUPB (Algemene Beginselen van Behoorlijk Bestuur) melalui cara konstruksi hukum. Yang berarti pengadilan administrasi tidak boleh menolak untuk memeriksa dan mengadili sesuatu perkara yang diajukan dengan dalih bahwa hukum tidak atau kurang jelas, melainkan wajib untuk memeriksa 
dan mengadilinya. Hakim sebagai penegak hukum dan keadilan wajib menggali, mengikuti, dan memahami nilai-nilai hukum yang hidup dalam masyarakat sebagai perwujudan asas ius curia novit. 


\section{DAFTAR PUSTAKA}

\section{A. Literatur Ilmiah}

Marzuki, Peter Mahmud, Pengantar Ilmu Hukum, (Jakarta: Kencana Prenada Media Group, 2009).

Marzuki, Peter Mahmud, Penelitian Hukum, (Jakarta: Kencana Prenada Media Group, 2009).

Mandiri Hadjon, Philipus, Pengantar Hukum Administrasi Indonesia, (Yogyakarta: Gadjah Mada University Press 2008).

Mandiri Hadjon, Philipus, Perlindungan Hukum Bagi Rakyat Di Indonesia, (Surabaya: Peradaban, 2007).

Purbopranoto, Koentjoro, Beberapa Catatan Hukum Tata Pemerintahan dan Peradilan Administrasi Negara, (Bandung: Alumni, 1981).

Wijoyo, Suparto, Karakteristik Hukum Acara Peradilan Administrasi (Peradilan Tata Usaha Negara), (Surabaya: Airlangga University Press, 2005).

Makalah/Artikel/Prosiding/Hasil Penelitian/internet:

Marzuki, Peter Mahmud, Sumber-Sumber Penelitian Hukum, (Surabaya: Handout Magister Hukum FH Unair, t.t.)

Website/internet: Gimana nih, Sudah Diputus MK Masih Juga Gugat ke PTUN, http://www.jpnn.com/read/2016/03/01/360599/Gimana-nih,Sudah-Diputus-MK-Masih-Juga- Gugat-ke-PTUN

\section{B. Perundang-Undangan}

Undang-Undang Nomor 8 Tahun 2015 tentang Perubahan atas UU No. 1 Tahun 2015 tentang Penetapan Peraturan Pemerintah Pengganti UU No. 1 Tahun 2014 tentang Pemilihan Gubernur, Bupati, dan Walikota menjadi UU (LNRI Tahun 2015 No. 57 dan TLNRI No. 5678)

Undang-Undang Nomor 9 Tahun 2015 tentang Perubahan Kedua atas UU No.

23 Tahun 2014 tentang Pemerintahan Daerah (LNRI Tahun 2015 No. 58 dan TLNRI No. 5679 disingkat UU Pemda) 
Undang-Undang Nomor 30 Tahun 2014 tentang Administrasi Pemerintahan (LNRI Tahun 2014 No. 292 dan TLNRI No. 5601 disingkat UU AP) Undang-Undang Nomor 8 Tahun 2012 tentang Pemilu Anggota DPR, DPD dan DPRD (LNRI Tahun 2012 No. 117 dan TLNRI No. 5316)

Undang-Undang Nomor 3 Tahun 2009 tentang Mahkamah Agung (LNRI Tahun 2009 No. 3 dan TLNRI No. 4958 disingkat UU MA)

Undang-Undang Nomor 48 Tahun 2009 tentang Kekuasaan Kehakiman (LNRI Tahun 2009 No. 157 dan TLNRI No. 5076 disingkat UU KK) Undang-Undang Nomor 51 Tahun 2009 tentang Perubahan Kedua UU No. 5 Tahun 1986 tentang Peradilan Tata Usaha Negara (LNRI Tahun 2008 No. 160 dan TLNRI No. 5079 disingkat UU PERATUN)

Undang-Undang Nomor 42 Tahun 2008 tentang Pemilu Presiden dan Wakil Presiden (LNRI Tahun 2008 No. 176 dan TLNRI No. 4924 disingkat UU Pilpres)

Undang-Undang Nomor 10 Tahun 2004 tentang Pembentukan Peraturan Perundang-undangan (LNRI Tahun 2004 No. 53 dan TLNRI No. 4389) 